\title{
Transformation of the
}

\section{Space in the context of}

Neoliberal Urbanization:

The Case of Izmir New

\section{City Centre, Turkey}

\section{Özgün Tutar ${ }^{*}$ Eylem Bal ${ }^{* *}$}

\begin{abstract}
The neoliberalism process of Turkey, the intersection point of the Global South and the Global North, which dates back to the 1980s when neoliberalism became a dominant paradigm in the world, began to rapidly transform urban space in the 2000s. With the transformation of capital out of İstanbul, the main application area of neoliberal urbanization in Turkey, the other metropolitan cities of Turkey have been involved in the process of neoliberalization. In İzmir, the third largest metropolitan city of Turkey, the area which is declared New City Centre (NCC) in 2003 has become one of the important application areas of neoliberal urbanization policies. The neoliberalization process of NCC is carried out through large-scale urban projects which are one of the important implementation tools of neoliberal urbanization policies and intervene in the economic, social and cultural areas as well as urban space. In this context, the aim of this study is decipher neoliberal urbanization-oriented process and variables of neoliberal urbanization
\end{abstract}

Keywords: Neoliberal urbanization, largescale urban projects, reproduction of space, Izmir new city centre, Turkey

*MSc in City and Regional Planning department in Dokuz Eylül University, Turkey ORCID

Email: ozguntutar@gmail.com

**Assist. Prof. Dr. in City and Regional Planning department in Dokuz Eylül University, Turkey (Corresponding Author) $O R C I D$ Email:eylem.bal@deu.edu.tr 
process in NCC and to reveal the neoliberal spatial transformation in the region on the basis of reproduction of the space.

\section{INTRODUCTION}

In the neoliberalization process, where the relationship between capital and state has been redefined in favor of economic growth, cities have become very important as the institutional laboratories of neoliberalization ( $\mathrm{He} \& \mathrm{Wu}, 2009)$. Because neoliberalism is not only an economical approach, it is also intertwined with urban political life (Theodore \& Peck, 2011). The neoliberal cities, which correspond to the reflection of the political and economic transformations on the space, undertook the task of meeting the needs of capital accumulation (MacDonald, 2011). Along with the neoliberalism that began to dominate the world in the 1970s, it was observed that the city was located at the centre of the neoliberal urbanization policies and transformed within the axis of these policies (Kozanoğlu, Gür \& Özden, 2008). In the twenty years, cities have been embedded in a geoeconomic framework characterized by positioning strategies and rapidly increasing inter-regional competition (Brenner \& Theodore, 2002). Internationalization of neoliberalism reproduces inequalities in global wealth and power and causes duality in economic and political atmosphere, similar to historical colonial empires (Radice, 2007). It is possible to talk about the polorized world: Global North which is mentioned by wealth, democratic governance, peace, technology, creativity, stability and Global South which is seen as a confusion, war, conflict, poverty, anarchy and oppression zone (Odeh, 2010). In this economic and political framework, cities in the South adopt the criteria set by the North, in order to integrate into the global economy and ensure competitiveness despite the risk of increasing social and spatial polarization (Lemansk, 2007). And today, no matter where the city is located in the world, the way of neoliberal approach to the city is the same with global cities and the ongoing neoliberalization process is similar but with larger negative consequences.

The concept of global city that emerged in this process aims to make cities more attractive for international capital and international companies (Burgers \& Van Der Vaal, 2008). With the popularization of the global city vision, the speculative real estate sector all by itself has become one of the most powerful accumulation tools of capital (Harvey, 2015). For this reason, neoliberal urbanization is defined briefly as a re-scaling of functions, activities and relations in the process of transforming urban land into a direct rent-generating commodity (Smith, 
2002). Mayer (2017) points out that neoliberal urbanization rises on four basis: growth-oriented urban strategy, entrepreneurial management, privatization and intensifying social polarization. Neoliberal urbanization process corresponding to a creative devastation leads to creative transformations such as destruction and /or intense surveillance of urban public areas on the built environment and urban form, creation of new privatization areas of destructive and elite consumption such as abandonment of community-oriented planning initiatives, production of largescale urban projects, production of purified areas where closed urban settlements and social structures are reproduced, intensification of socioeconomic polarization by the expansion of the gentrification boundary and the determination of the principle of "the highest and the best use" as the basis of large land usage decisions (Brenner \& Theodore, 2002, 371). The old port and industrial areas are transformed into business quarters with museums and other buildings of culture to attract creative class and capital investments (Andersen \& Røe, 2017). In the process of transformation, public spaces evolved into alternative public spaces, including shopping centers, on the grounds that they cannot fulfill their roles. And with this change, it is possible to talk about the exclusion of "undesirables" and control in public space (Gomes, 2019).

City centres are seen as "live, work and play" areas for the wealthy middle and upper classes (Marquardt \& Füller, 2012). Therefore, entrepreneurial urbanization policies, encouraged by neoliberal policies, are put into practice through the construction of prestigious large-scale projects (Enright, 2014). In order to create the consumption areas needed by neoliberal urbanization, attract the creative class to the city, bring more profits to the enterprises and provide urban rent increase, large-scale urban projects have become an important strategy in the market leadership for economic development (Rankin \& Delaney, 2010). Large-scale urban development projects are highly risky investments for the city due to their speculative economic viability and the dynamics of the real estate sector (Swyngedouw, Moulaert \& Rodriguez, 2002). In addition to the risks they have, they cause displacement of urban residents and gentrification processes that cannot tolerate the rent to be earned because they are rent-based acquired from the re-evaluation of urban land (Evans, 2005). The commodification of urban land, which is an important feature of neoliberalism, has become a state project widely applied in many cities of the world (Lin \& Zhang, 2015). While the gentrification is now becoming an application that is more institutionalized, facilitated by the state and encountering less resistance, it has made all cities, regardless of scale, disambiguate to social 
polarization (Hackworth, 2007). The urban elite's indifference to impoverishment and greed against the rent in spite of the growing despair of the urban poor and its anger towards the system, increase the visibility of the differences between the social groups, causing the conflict becoming more violent (Sassen, 1998).

Cities shaped by neoliberal urbanization are transforming into 'extraordinary wealth and privilege islands with their rising skyscrapers such as millions of square meters of office areas and towers' (Harvey, 2015, 70). The most socially destructive result of the process was the reorganization of the urban centers for the upper and upper-middle classes, while the lower classes were pushed to the outer walls of the city (Kozanoğlu and other, 2008). Due to the exclusion of the productive class from urban space, the neoliberal city forms the basis for the overcoming of social divisions (MacDonald, 2011). In theory, while creating cities in conformity with world standards, in practice, elite cities that are becoming enemy for the urban poor, are being created focused on new wealthy citizens and consumption-oriented lifestyles (Ellis, 2012). The residential displacement of slum areas occurs on a massive scale in the Global South compared to the Global North due to large-scale urban development projects undertaken by entrepreneurial states (Borsuk \& Eroğlu, 2019). It is possible to say that neoliberalization, which is defined as the driving force of the re-creation of urban space on the world scale, works unequally for different groups of society (Bénit-Graffou, Didier \& Peyroux, 2012).

In this framework, Turkey the intersection point of the Global South and the Global North, has not historically undergone colonialism and post-colonial political processes like Latin America, Africa or South Asia, is special case in the era of neoliberalization and global imperialism. However, the port cities of Turkey, are subject to a process similar to colonialism due to capitulation in the late Ottoman period (Yıldız, 2014). Therefore, it is possible to say that the port cities of Turkey has a close experience with the Global South. Cities in Turkey offer unique examples rather than cities of North or South, due to unique political, economic and geographic features of country. Especially with the acceleration of Turkey's neoliberalization process in the post-2000 period, it is seen that both neoliberal urbanization will find application area with the large areas in the metropolitan cities with the support of the state. In this paper, New City Centre of İmir (NCC), the focus of the neoliberal urbanization in Turkey, has been selected as case study due to providing a unique example in terms of changing the location of hundreds of years old city centre and an area of 480-hectare, tabula rasa, for neoliberal 
urbanization applications. Study aims to decipher the ongoing neoliberalization process in NCC which has quite different dynamics than North or South, in the light of large-scale projects as neoliberal application tools finding application area under these unique city dynamics. Privatization processes and largescale urban projects, which are one of the important application tools of neoliberal urbanization, and it can be said that these are the embodiment of neoliberalization as they provide maximum profitability in minimum area as well as transfer the profit in the field to capital. In this direction, the objectives of the study are concentrated on revealing the concrete and abstract outputs of the large-scale projects, important application tools of neoliberal urbanization, located in NCC throughout the planning periods of NCC.

At this point, the plans are very important because they contain the land use decisions and construction conditions that enable the construction of large-scale projects through the decisions taken. Therefore, it is necessary to take into consideration the organizations where the plans are approved as well as the contents of the plans. Because, in addition to the plans approved by the local government, the plans prepared by the central government provide important data for the deciphering of the relationship between public and capital, as well as the privatization processes which are one of the important tools of neoliberal urbanization. In this paper beside the brief planning history that enable the construction of large-scale projects, changes in land use pattern, urban rent, city silhouette and property pattern, the parameters of the spatial, economic and social outputs can be read easily, are examined as indicator of reproduction of space in order to measure the concrete and abstract effects of the large-scale projects on the city. Within the scope of the study, these parameters are considered as important outputs in the transforming the space process of neoliberal urbanization due to the fact that they change the spatial, economic and social texture of the city in addition to being easily readable.

\section{A NEW STOP IN NEOLIBERAL URBANIZATION: İZMIR}

Turkey entered the process of neoliberalization with 1980s but concrete outcomes of neoliberalization on the space have emerged along with the acceleration caught in 2000s. Turkey's urbanization experience after 1980 can be defined as 'early neoliberal urbanization phase' between 1980-2000 and 'neoliberal urbanization phase' covering the post-2000 and the city where the clear reading of the signs of neoliberal urbanism in this process in Istanbul, the focus of capital (Bal, 2011, 1). In 
Turkey's neoliberal urbanization phase of that affect the urban development process, capitalism and entrepreneurship come into prominence as keywords. Turkey's urban development at this point, giving a response in a different way than in the West; the bottom-up hybrid model, in which 'authoritarian power combined with horizontal patronage and networking capacities of individuals, creating new opportunities for the power-holders, while the power-holders are producing for themselves (Şanlı \& Townshend, 2018, 1247-1248).

Turkey's increased global functions and foreign capital inflow as a part of the effort to integrate into the global economy in 1980s resulted in İstanbul to become the focus of neoliberal urbanization (Eraydın, 2011). However, in the neoliberalization process of İstanbul the ghetto areas, exclusion and struggle in the background were ignored while constructing the highways, shopping centers, hotels and modern buildings (Robins \& Aksoy, 1995). In the period after 2000, with the capital moved out of İstanbul at the same time, the other large metropolitan cities of the country started to be the focus of neoliberal urbanization. In this period, urbanization in Turkey carried out by large-scale projects in areas attracting urban elites and capital (Güzey, 2016). Large-scale projects, whether urban renewal projectsor gated communities, make visible the border of spatial segregation, which is a long time in Turkey (Güzey, 2014). İzmir, Turkey's third largest city, is seen to become prominent in this regard, to become one of the most popular cities in terms of top-scale real estate investments of the large-scale construction companies. İzmir showed a tendency to be far and behind the neoliberal urbanization tendencies in the historical process, but in the 2000s, aforesaid policies started to be effective in the city and the concrete outputs that require large capital investment became prominent in the post-2010 period (Bal \& Altun 2016). It is important to analyze urban local dynamics within the context of urbanization processes in order to reveal the trends of the city in the neoliberal urbanization process and the changes experienced in this context.

\section{NEW CITY CENTRE AS THE MOST POWERFUL REFLECTION OF NEOLIBERAL URBANIZATION IN İZMIR}

The neoliberal urbanization process of İzmir gained a great acceleration with the 2000s. In parallel, the expansion of sustainable urban development practices in the world was reflected as the adoption of port-oriented urban development strategies in the planning process of İmir and carried the port, that is located in the centre of the city geographically and its close 
surroundings to the focus of planning studies. The position of the region in urban development strategy has become very important with the establishment of the new urban centre with the 1/5000 scale İzmir New City Centre Master Plan, which was approved in 2003, and the 480-hectare area including the Turan, Salhane and Alsancak Port Back Regions. NCC that is connected to Kemeralt, which is the traditional city centre of Izmir and Karşlyaka and Bornova, which are the city's secondary centres, through the main arteries of the city, has become an attractive area for realizing the neoliberal urbanization practices not only because of its geographical location, but also having an appropriate land inventory for the positioning of the uses required by the city centre. The fact that the private sector, which is the most powerful actor of the neoliberal urbanization process, turned its route into NCC, shows that the city has started to be considered as an alternative to Istanbul in terms of investment opportunities and potentials.

In the neoliberal urbanization process of İstanbul, it is possible to talk about the pioneering role of a single actor in drawing a new route, although the behavior of each actor does not constitute a clear pattern (Taşan-Kok, 2015). Parallel to this, it is very important to reveal the effects of the individual movements of the actors who manage the process, as well as the behaviors of the public, private sector and civil society, which form part of a whole, to explain the neoliberal urbanization process in İzmir, which is an alternative to Istanbul on the neoliberal urbanization agenda. For this reason, in order to understand the neoliberal urbanization process experienced in the NCC, it is necessary to evaluate the plans, which are the legal basis for enabling the production of space and the large-scale urban projects that have become significant as the most basic implementation tool of the intervention to the space in question together.

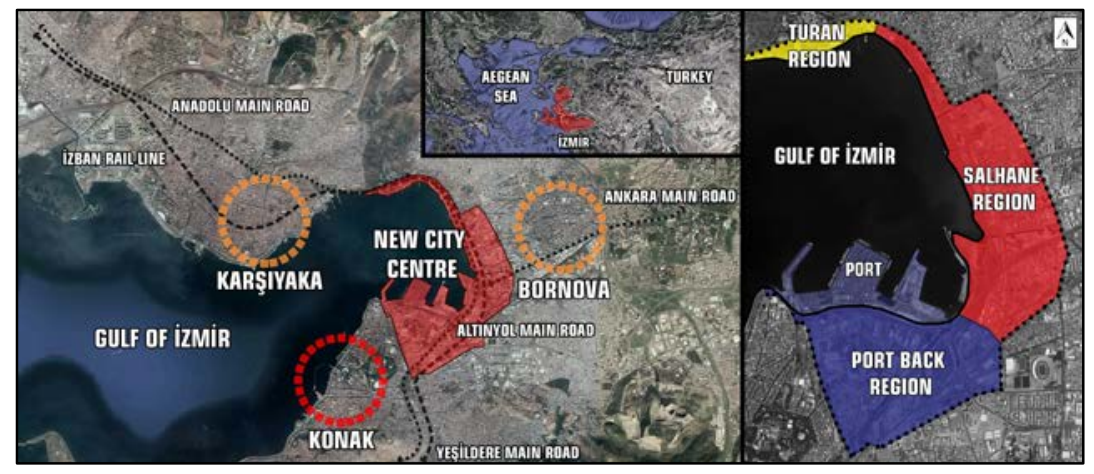

Figure 1. NCC's location in the city and NCC Zones (Drawing by author) 


\section{Brief Planning Story of NCC}

The plans as a legal basis of the transformation in NCC, play a critical role in the transformation process of NCC due to the construction conditions and usage decisions in proportion to their vision. In addition to this, it is important to know the planning history of the area in order to monitor the development of projects which are the dynamos of the transformation process of NCC. At this point, planning history of NCC shows that the area is subject to transformation after 2001 (Figure 2). Therefore, the study focused on the large-scale projects are announced between 2000 and 2018 and the conditions that enable large-scale projects to be implemented.

Figure 2. The process of shaping NCC vision (References, Plans)

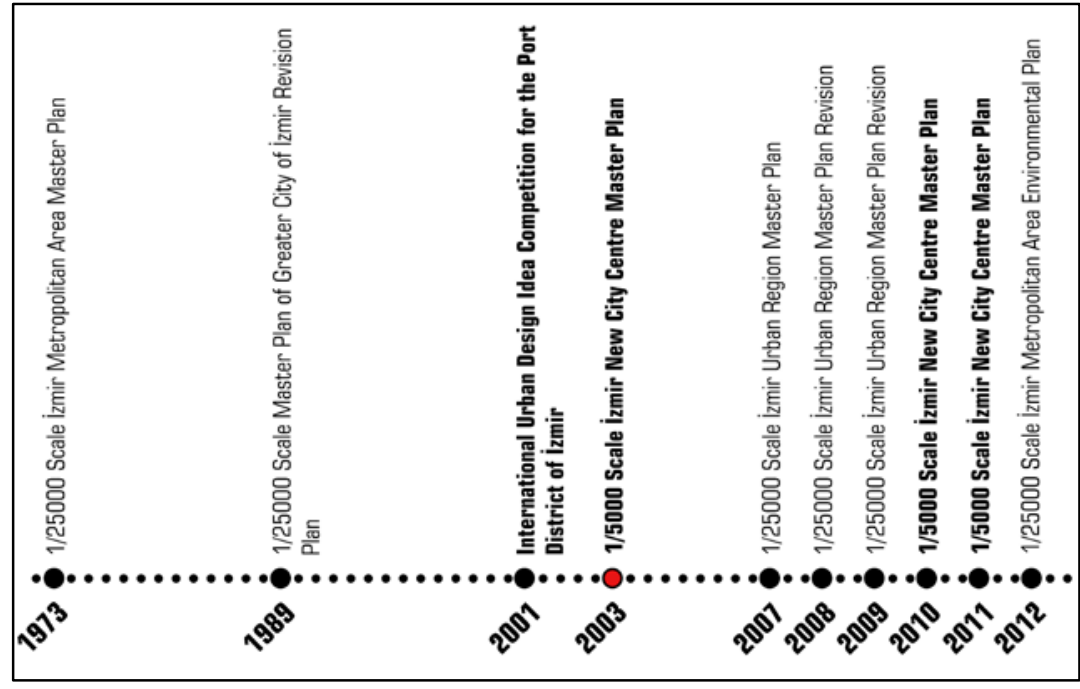

The integration of the north and south of the city, give acceleration to the development of the city, changing the view of the city and increasing the urban life quality, which are among the targets of the $1 / 5000$ scaled İzmir New City Centre Master Plan, approved in 2003, which has declared the area as NCC and which is the first plan that focused on the area, are basis for the subject planning works and the same time, showing the vision of NCC in the city. Reorganizing the idle industrial and storage areas as CBD, being flexible about the building height and creating a new identity, which are among the targets of the 1/5000 Scaled İzmir New City Centre Master Plan shows the vision related to NCC, also provided obtaining plots that will provide making new projects through decentralization of the industry and the basis of the spatial transformation indirectly (Izmir Metropolitan Municipality, 2003). Although the current plan targets were preserved to a large extent with the vision of the $1 / 5000$ Scale İzmir New City Centre Master Plan, which was approved in 2003, reaching to the quality of 'not the place being transited, but came for it', that was included in the plan at the $1 / 5000$ Scale İzmir New City Centre Master Plan approved in 2010, a more comprehensive city vision is seen to be 
adopted with the objectives of creating the city centre that offers the new urban images in accordance with the developing international status of İzmir (İzmir Metropolitan Municipality, 2010). 1/5000 Scale İzmir New City Centre Plan, which was approved in 2011, which has small differences between the 1/5000 Scale İzmir New City Centre Plan, which was approved in 2010 in terms of spatial decisions and from which the statement of 'transfers can be done among the uses' was removed, is in effect with the version with partial plan changes (İzmir Metropolitan Municipality, 2011).

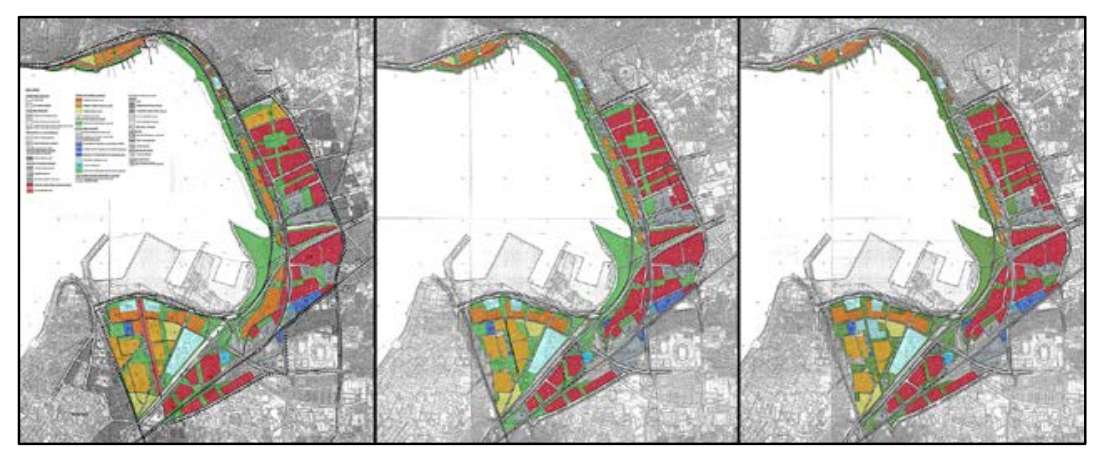

The 1/5000 Scale Master Plans for the NCC contain information on land use decisions and construction conditions. For this reason, the plans give an idea about the dimensions of the physical transformation projected by NCC in addition to land use. Regarding the use of CBD in the 1/5000 Scale Master Plans, Turan, Salhane Region and a large part of the Port Back Region, 'all kinds of trade, downtown, office, office block, commercial storage, bank, insurance, multi-storey shops and entertainment places, housing, multi-storey vehicle park and private hospital may take place. One or more of these uses can be found in the same plot' statement takes place. Despite the regionalization, it is seen that the concept of mixed use has been adopted throughout NCC when the definitions related to the uses on the area are taken into consideration. Related to the minimum plot size in the plans, 'the size of the minimum zoning lot will be $5000 \mathrm{~m} 2$ for CBD (central business area), tourism + trade and tourism + trade + culture areas (except for special planning areas)' statement takes place (İzmir Metropolitan Municipality, 2003; İzmir Metropolitan Municipality, 2010; İzmir Metropolitan Municipality, 2011). It is possible to say that when the conditions given for the different uses in NCC and the minimum plot size are considered together, it is foreseen that high-rise construction is foreseen.
Figure 3. 1/5000 Scale İzmır New City Centre Master Plan from 2003, 2010 and 2011 (References, Plans) 
Table 1. Construction conditions of $1 / 5000$ Scale İzmir New City Centre Master Plans from 2003, 2010 and 2011 (Edited from data of References, Plans)

1Plot Coverage 2Floor Area Ratio

\begin{tabular}{|l|r|r|r|r|r|r|}
\hline \multirow{2}{*}{ Land Use } & \multicolumn{2}{|c|}{$\mathbf{2 0 0 3}$} & \multicolumn{2}{c|}{$\mathbf{2 0 1 0}$} & \multicolumn{2}{c|}{$\mathbf{2 0 1 1}$} \\
\cline { 2 - 7 } & PC $^{1}$ & \multicolumn{1}{c|}{ FAR $^{2}$} & \multicolumn{1}{c|}{ PC } & \multicolumn{1}{c|}{ FAR } & \multicolumn{1}{c|}{ PC } & \multicolumn{1}{c|}{ FAR } \\
\hline CBD & 0.30 & 3.50 & 0.40 & 3.50 & 0.40 & 3.50 \\
\hline $\begin{array}{l}\text { Tourism, } \\
\text { Commercial }\end{array}$ & 0.35 & 3.00 & 0.35 & 3.00 & 0.35 & 3.00 \\
\hline Tourism, Housing & 0.50 & 2.50 & -- & 2.50 & -- & 2.50 \\
\hline $\begin{array}{l}\text { Tourism, } \\
\text { Commercial, Culture }\end{array}$ & 0.35 & 3.50 & 0.45 & 3.00 & 0.45 & 3.50 \\
\hline Commercial & 0.50 & 1.00 & 0.30 & 0.60 & 0.30 & 0.60 \\
\hline Housing & 0.50 & 3.00 & 0.50 & 3.00 & 0.50 & 3.00 \\
\hline
\end{tabular}

After the announcement of the area covering Turan, Salhane and Liman regions as İzmir New City Centre, many plans and plan changes were in question. However, there are plans and plan changes related to the areas subject to privatization, which are not included among the large-scale plans, but indicate that the area has been reshaped in the neoliberal urbanization axis (Table 2). Plots located at different points of NCC through plans are privatized by the central government in order to produce projects by private and public sector. It is seen that prestigious and big projects such as Folkart Towers, Mahall Bomonti İzmir and İzmir Cruise Port-İzmir Freight Port are located in the privatized areas. In this context, it is possible to consider these projects as the tendencies of the central government in the framework of neoliberal urbanization to facilitate the private sector's activity in NCC.

Table 2. Plan changes related to privatizations in NCC (Edited from data of References, Plans)

\begin{tabular}{|l|c|}
\hline \multicolumn{1}{|c|}{ Plan } & Approve \\
\hline $\begin{array}{l}\text { İzmir Province Karş1yaka County Salhane District 1134 Islands, } 4 \\
\text { Parcels 1/5000 Scale Master Plan }\end{array}$ & $28 / 01 / 2008$ \\
\hline $\begin{array}{l}\text { İzmir Province Konak County Halkapınar 1443 Island 37 and } \\
\text { 1454 Island 23 Parcels 1/5000 Scale Master Plan Change }\end{array}$ & $25 / 06 / 2012$ \\
\hline İzmir Cruise Port Area Master Plan Change (1/25000 Scale) & $30 / 04 / 2012$ \\
\hline İzmir Cruise Port Area Master Plan Change (1/5000 Scale) & $30 / 04 / 2012$ \\
\hline $\begin{array}{l}\text { İzmir Province Konak County Mersinli District 2876 Island 12 } \\
\text { Parcel Master Plan Change }\end{array}$ & $24 / 02 / 2014$ \\
\hline $\begin{array}{l}\text { İzmir Freight Port Izmir Metropolitan Area Environmental Plan } \\
\text { Change }\end{array}$ & $03 / 11 / 2015$ \\
\hline İzmir Cruise Port Area Master Plan Change & $03 / 11 / 2015$ \\
\hline İzmir Freight Port Area Master Plan Change & $03 / 11 / 2015$ \\
\hline $\begin{array}{l}\text { İzmir Freight Port Izmir Metropolitan Area Environmental Plan } \\
\text { Change }\end{array}$ & $02 / 05 / 2016$ \\
\hline İzmir Cruise Port Area Master Plan Change & $02 / 05 / 2016$ \\
\hline İzmir Freight Port Additional and Revision Master Plan & $02 / 05 / 2016$ \\
\hline $\begin{array}{l}\text { İzmir Province, Konak County, Kuruçay and Umurbey Districts, } \\
\text { 7839 Island 1 Parcel, 7840 Island 1 Parcel, 1384 Island Various } \\
\text { Parcels, 1445 Island Various Parcels, 1448 Island Various Parcels } \\
\text { and Perimeter of 1/5000 Scale Master Plan Change }\end{array}$ & $10 / 05 / 2017$ \\
\hline
\end{tabular}


When the lower and upper scale plans are taken as a whole based on the planning history of the area, it is seen that there is a situation contrary to the plan hierarchy. However, the fact that the NCC vision is based on the International Urban Design Idea Competition for the Port District of Izmir instead of the upper scale plans, shows that the fragmentary plans developed in contradiction with the planning hierarchy are the product of a projective approach. In this context, it is possible to say that a radical transformation of NCC is foreseen in terms of both land use texture and construction conditions and in this process, transformation is shaped within the vision of making the city attractive for capital by means of large-scale projects based on mixed use and high-rise construction.

\section{Large-Scale Urban Projects with Neoliberal Urbanization in NCC}

The upper and lower scale plans developed for NCC have prepared the appropriate legal ground and conditions for the implementation of neoliberal urbanization practices and have drawn the general framework of the dimensions of the transformation. In order to be able to read the neoliberal urbanization process in detail, it is necessary to examine largescale urban projects. At this point, the physical qualities of the projects, the area chosen, investment costs, investors, the years of their realization and the elements of prestige are of great importance. In addition, the projects not only lead some basic transformations to the plot they are located in, but also in the immediate vicinity and indirectly over the city.

It is expected that the total value of the investments that have chosen place in NCC in the year 2030, which is the target year of the NCC plans preparing the appropriate legal ground for neoliberal urbanization, will exceed 18 billion dollars. This situation shows that NCC capital being the main focus in Izmir, also show that it is targeted for Izmir to come to an important point in capital inflows in Turkey. In determining the dimensions of the transformation in the NCC, land use decisions within the scope of large-scale urban projects, increase in urban rent and change in urban silhouette stand out as important parameters. In this study, the process of re-production of urban space is tried to be explained; by taking the periods in which the projects were implemented in consideration that the concrete and abstract outputs of the city that can be observed, in the axis of 20 largescale urban projects that have chosen place in NCC. These 20 large scale projects stand out from other projects in the city with their investment costs, total construction sites and investor profiles. However, the fact that the projects are clustered in a certain area 
instead of single parcels scattered within the city provides important data for neoliberal urbanization that transforms the space of NCC.

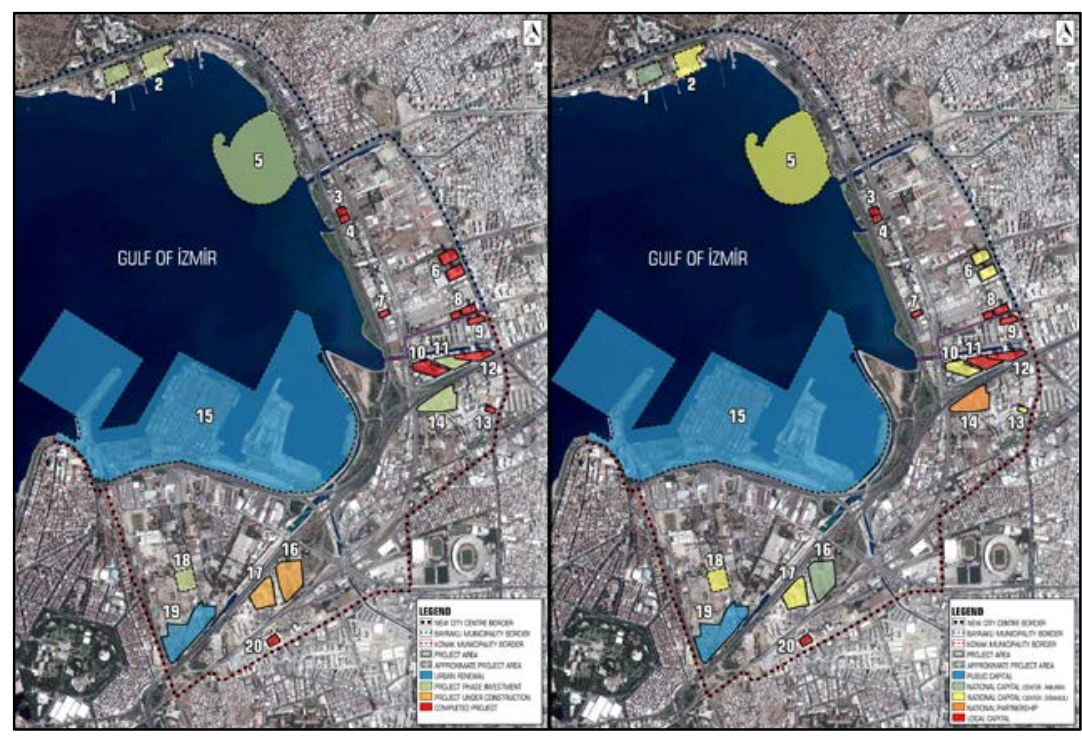

Figure 4. Distribution of large-scale urban projects in İzmir NCC (Drawing by author)

${ }^{1}$ References, Online Resources 1

${ }^{1}$ References, Online Resources 2

1 If there is difference between original titles and international titles of companies, international titles was used. ${ }^{1}$ Approximate value considered (1 USD= 5.42 TRY in 11/01/2019)

Table 3. Featured Projects in Izmir New City Centre ${ }^{1}$, locations in $1 / 1000$ scale implementary development plans and project details ${ }^{2}$

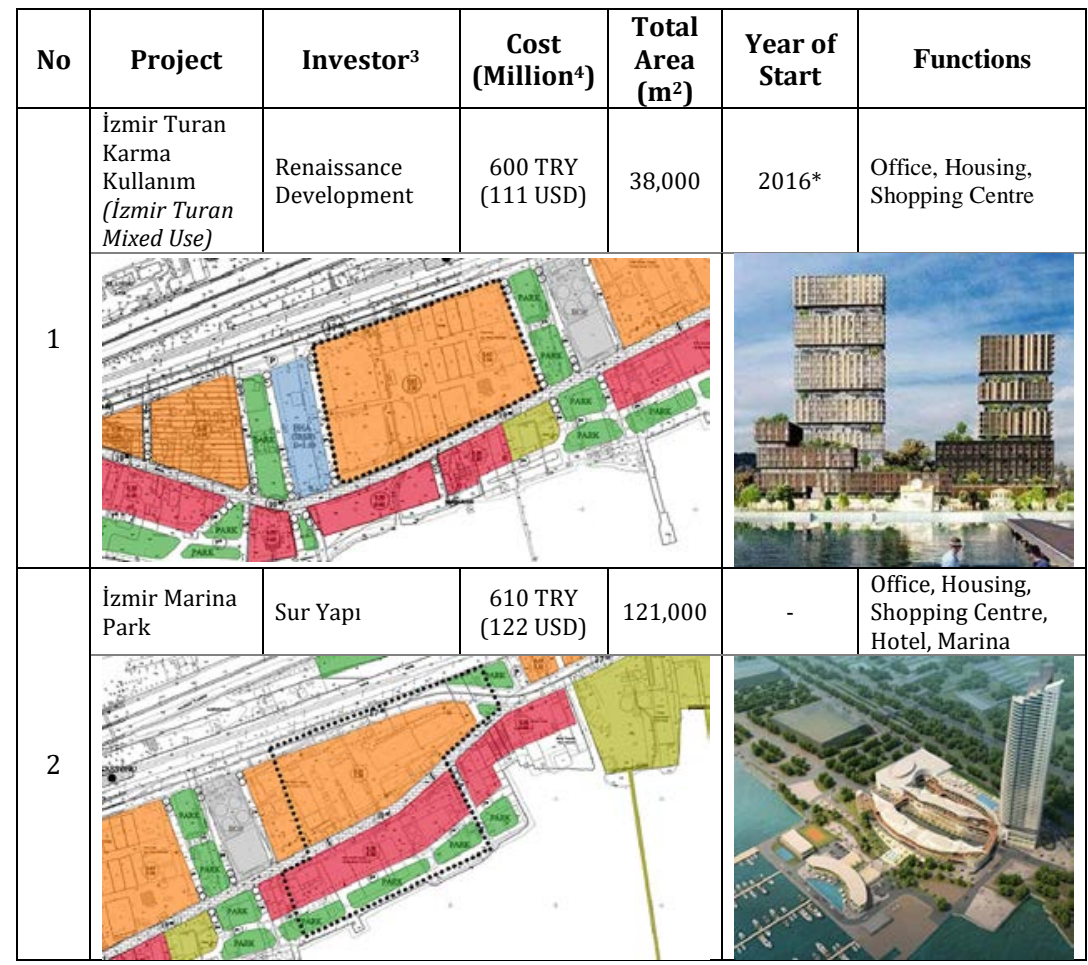


Transformation of the Space in the Context of Neoliberal Urbanization: The Case of Izmir New City Centre, Turkey

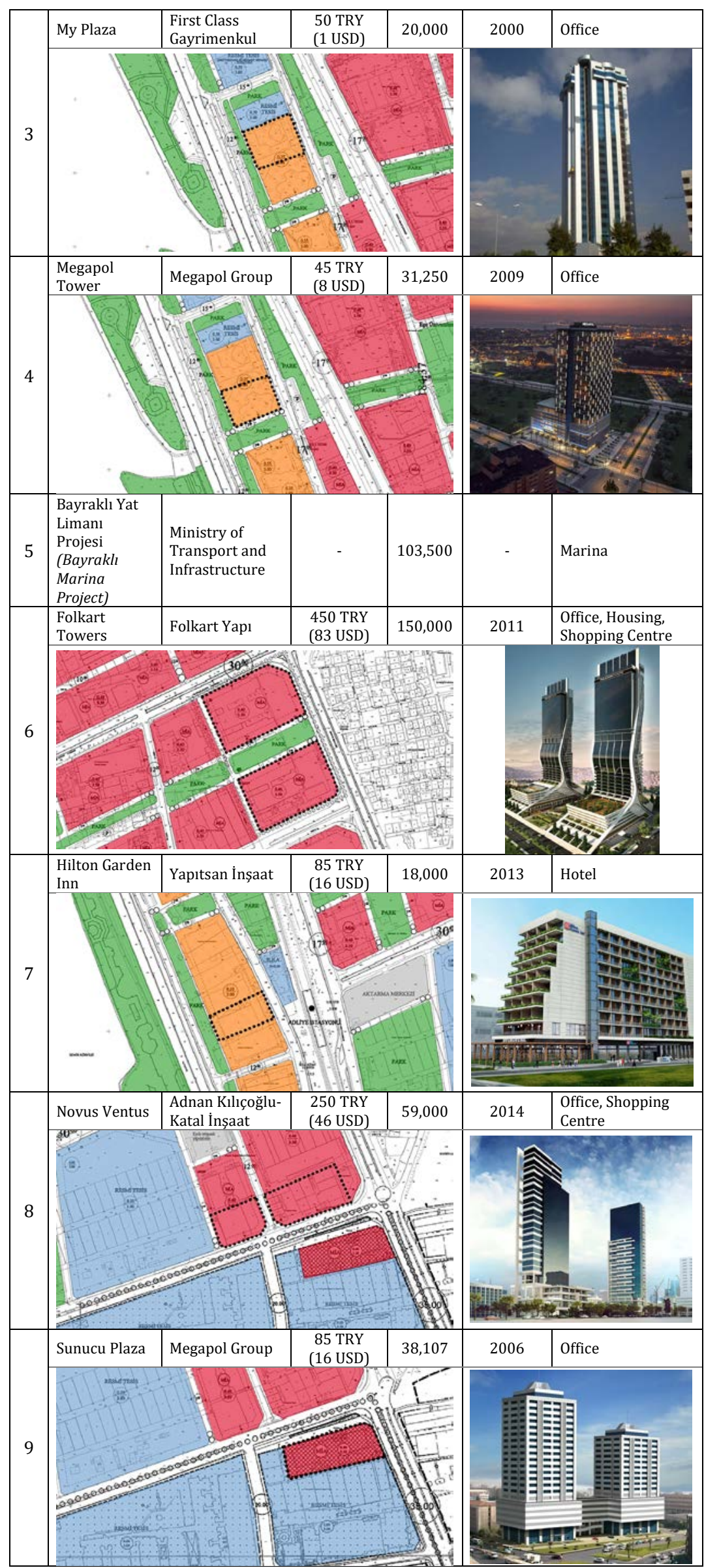







Transformation of the Space in the Context of Neoliberal Urbanization: The Case of Izmir New City Centre, Turkey

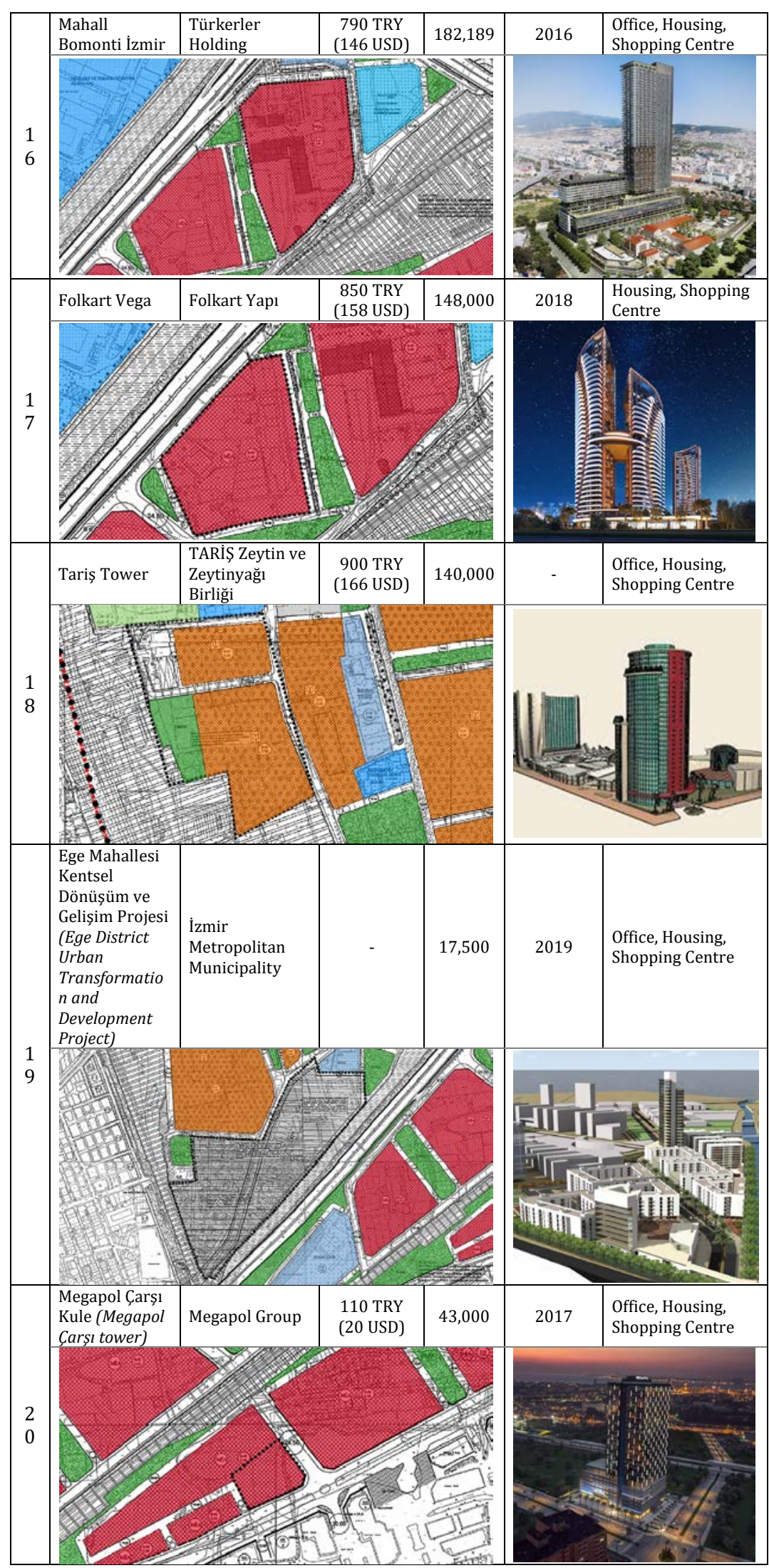

In the light of the projects examined within the scope of the study, three main periods have been determined by taking into 
consideration the planning process related to the area in order to reveal the transformation in NCC:

- Period Before 2003: The period before 1/5000 scale İzmir New City Centre Master Plan, in which the area is declared as NCC and there is no separate plan related the area within the boundaries of NCC.

- Period Between 2003 - 2011: The period between the 1/5000 scale İzmir New City Centre Master Plan and the date when the $1 / 5000$ scale Master Plan studies related to the area were completed.

- Period After 2011: The period after the completion of the $1 / 5000$ scale Master Plan related to the area.

When analyzed according to years, it is seen that there has not been a large capital mobility until the legal basis was prepared in 2011 within three periods that NCC has experienced. However, with the preparation of the legal base, it is seen that the number of projects that have chosen place in NCC has increased rapidly as the national capital begins to tend towards to NCC. Nevertheless, four main parameters are emphasized in order to determine the nature of the transformation and the interest of capital in the area:

Investment Cost: When the investment costs, which are one of the most powerful parameters that show the capital size of the projects in NCC, are examined, it is seen that the investment costs of NCC projects have increased over the years. It is seen that 900 million TRY, which is the value of the total investment made to the area until the year 2011, the date the planning process of NCC was completed, then reached 5 billion TRY, which was approximately six times in six years, rapidly growing after the legal basis is prepared. In this increase, especially in 2013 and 2016, the breakpoints coincide with the projects of high prestigious mixeduse projects such as Mistral Izmir (950 million TRY) and Mahall Bomonti Izmir (790 million TRY) which are among the highest investment cost projects of NCC.

Figure 5. The number of projects produced in NCC during the year and the total investment amount according to project start years (Drawing by author)
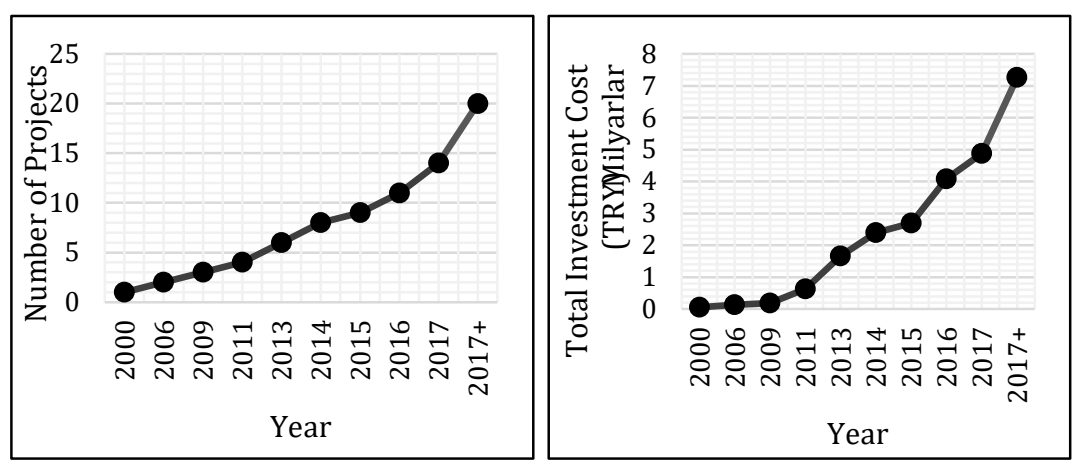
Investor Group: In addition to the investment value of NCC projects, the nature of the investing capital group is also very important in terms of neoliberal urbanization dynamics. With the completion of NCC plans in 2011, the number of national capital groups investing in the area has increased. However, it is observed that local capital efficiency has reached approximately twice as compared to previous periods. This shows that the NCC has reached an important point for capital on a local and national scale. In addition, in response to 8 national capital groups that were present after 2011, 10 national capital groups are operating on the area. This shows that after 2011, the national capital began to lead the transformation process of the area, which was carried out by the local capital in the period before 2011 .

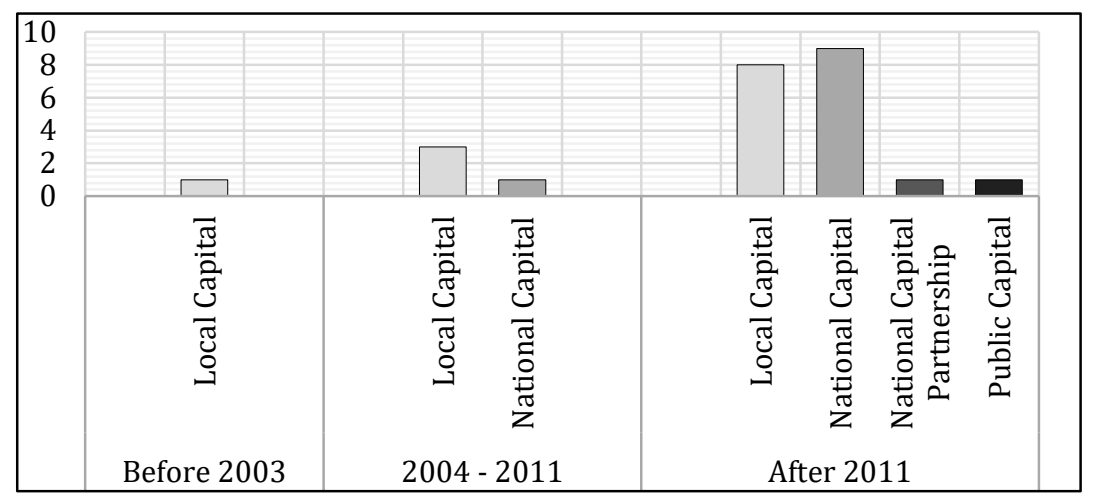

Functions Included in Projects: NCC shows an increase in investment costs and investor profile after 2011. Parallel to this trend, the functions of the projects after 2011 were diversified. $80 \%$ of the projects produced prior to 2011 are seen to have office use only, only $20 \%$ of the projects produced after 2011 are seen to have office use. More than $80 \%$ of the projects produced after 2011 have the office, residence and shopping mall use while the remaining projects have office and shopping mall use. However, after 2011, there are different uses such as hotels and marinas in mixed-use projects. From this point of view, it is possible to say that the projects have been transformed into a more complex structure with the projects being designed to have more functions over time.
Figure 6. Distribution of capital groups according to periods (Drawing by author) 
Figure 7. Distribution of functions according to periods (Drawing by author)

Figure 8. Distribution of building heights and floor quantities according to periods (Drawing by author)

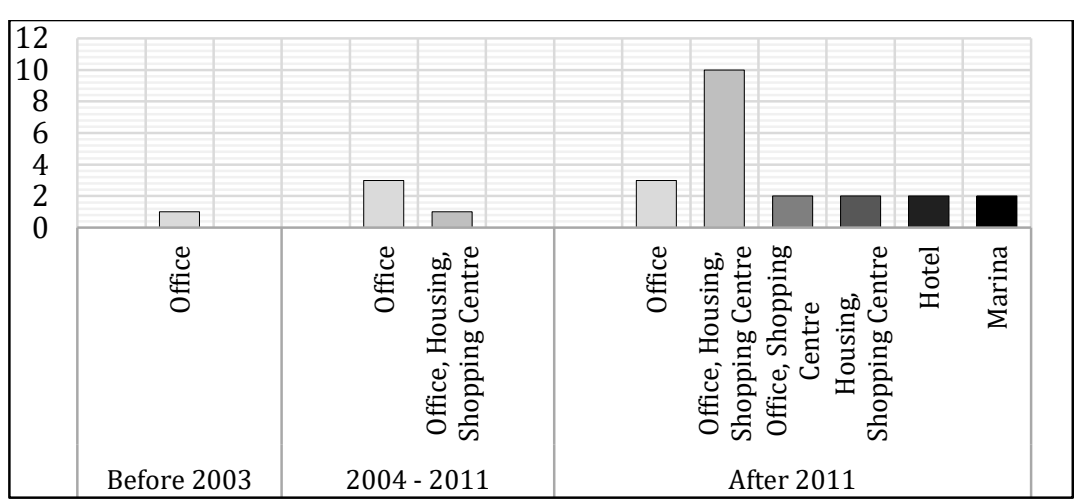

Building Heights: In parallel with the tendency to create more complex projects by diversifying the functions over time, the building height is increasing. Considering the projects produced after 2011, the number of buildings higher than 200 meters increased significantly. However, after 2011, there was a large increase in the number of high-performance structures with a height of less than 200 meters. Considering both cases, it is possible to say that the height of the projects in NCC has increased. When these two trends are taken into consideration, it is seen that the resulting table coincides with the objectives of the projects to be high prestigious in terms of investors.

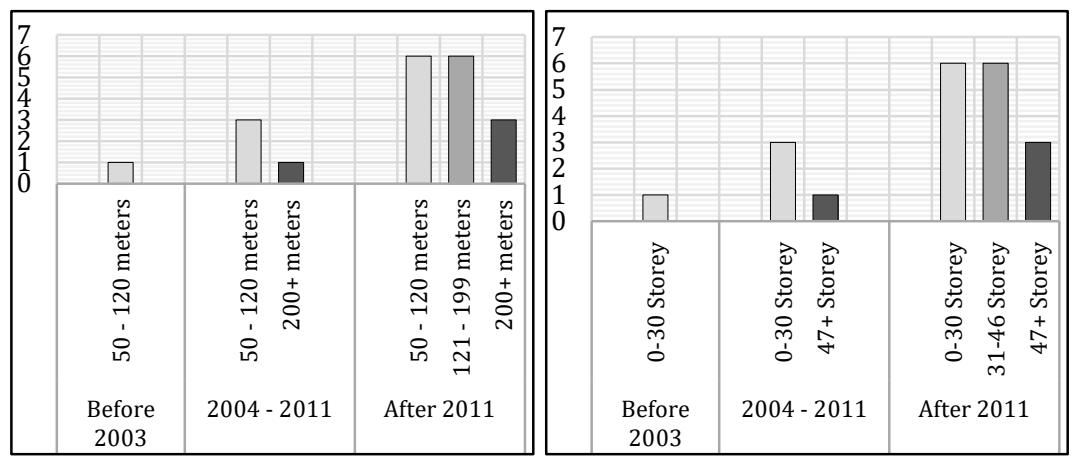

In the light of the four parameters examined, the spatial change, which was clearly realized in the NCC and planned to be realized, is the fact that the city centre transformed its economic and social environment, especially the spatial, within the framework of neoliberal urbanization. It is seen that the private sector and the public sector take place among the actors of this change carried out on the urban place on the basis of large national and local capital groups. The increase and diversification of private sector actors over time has accelerated the process of transformation of space by enabling larger investments and larger projects to choose place in space. 


\section{Parameters to Transformation of Space in NCC}

The NCC vision, in which the planning process draws the lines of its limits, is realized through large-scale projects that are especially investments belonging to the private sector. The vision that is being realized corresponds to the spatial, social and economic transformation of NCC. However, in order to reveal the process of re-production of space in NCC, it is necessary to reveal the concrete reality in the space and the effects of this change. For this reason, the process of re-production of space in NCC is explained through four basic factors as the change in land use pattern, the change in property pattern, the change in the urban rent fabric that the new spatial structuring on revealing the change in effects of economic structure of NCC and İzmir, and change in urban silhouette which have effects on urban identity and sense of belonging of urban residents as well as physical effects. These four basic parameters correspond mostly to the spatial, social or economic transformations, but each parameter has multidimensional effects on the city and its inhabitants due to characteristics of the paremeters.

\section{Change in Land use pattern in NCC}

When NCC's existing land use texture and plan decisions are compared, it is possible to say that there will be radical changes in spatial scale in NCC. There is an increase in the use of green areas, roads, education, health, cultural facilities and public institutions. However, although the increase in the functions is positive for the city, there is no data on whether this is a benefit for public. On the other hand, when the table is examined, the existing housing and trade units in the area are decreasing, while the utilization of CBD, which can accommodate both functions has a large proportion of $18.48 \%$ in the area, presents data on the dimensions of the transformation. In addition to these, functions connected with the main arteries divided into zones in a compatible manner with each other created a positive situation for the organization of the space of NCC. However, despite the increase in the total area, the fact that new connections are not established to feed the main arteries and reduce the increased burden on NCC raises the question of whether the roads within the NCC can tolerate the increasing number of users. 
Figure 9. NCC's existing general land use and land use according to the implementation plan of NCC (Drawing by author)

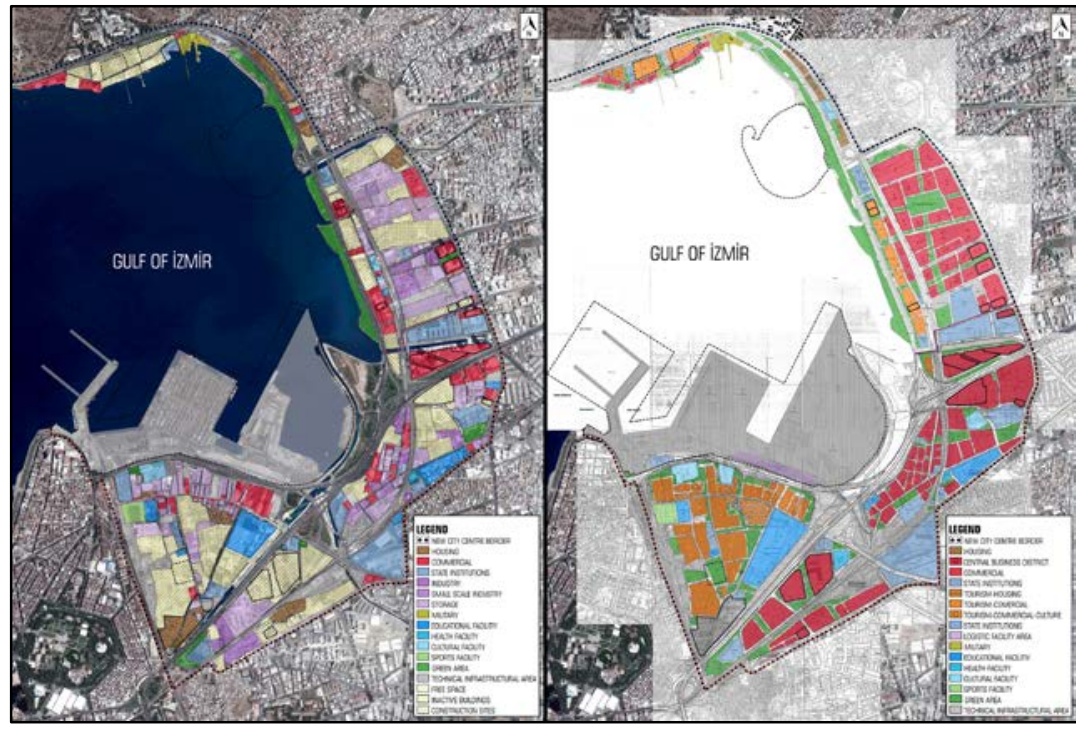

Table 4. Values of NCC's existing general land use and land use according to the implementation plan of NCC

\begin{tabular}{|c|c|c|c|c|}
\hline Land Use & $\begin{array}{l}\text { Existing } \\
\text { Land Use } \\
\text { (hectare) }\end{array}$ & Percentage & $\begin{array}{l}\text { Land Use } \\
\text { According } \\
\text { to the Plan } \\
\text { (hectare) }\end{array}$ & Percentage \\
\hline Housing & 12.52 & $2.61 \%$ & 2.39 & $0.50 \%$ \\
\hline $\begin{array}{l}\text { Central Business } \\
\text { District }\end{array}$ & 0 & $0, \%$ & 88.73 & $18.48 \%$ \\
\hline Commercial & 34.55 & $7.20 \%$ & 2.82 & $0.59 \%$ \\
\hline State Institutions & 30.23 & $6.30 \%$ & 32.57 & $6.79 \%$ \\
\hline Industry & 6.53 & $1.36 \%$ & 0 & $0 \%$ \\
\hline Small Scale Industry & 9.79 & $2.04 \%$ & 0 & $0 \%$ \\
\hline Storage & 51.91 & $10.81 \%$ & 0 & $0 \%$ \\
\hline Military & 2.00 & $0.42 \%$ & 2.00 & $0.40 \%$ \\
\hline Educational Facility & 12.58 & $2.62 \%$ & 15.92 & $3.32 \%$ \\
\hline Health Facility & 0.60 & $0.12 \%$ & 1.53 & $0.32 \%$ \\
\hline Cultural Facility & 2.53 & $0.53 \%$ & 5.10 & $1.06 \%$ \\
\hline Sports Facility & 2.07 & $0.43 \%$ & 2.07 & $0.43 \%$ \\
\hline Green Area & 14.93 & $3.11 \%$ & 54.32 & $11.32 \%$ \\
\hline $\begin{array}{l}\text { Technical } \\
\text { Infrastructural Area }\end{array}$ & 129.52 & $26.98 \%$ & 129.52 & $26.98 \%$ \\
\hline Tourism-Housing & 0 & $0 \%$ & 2.85 & $0.59 \%$ \\
\hline $\begin{array}{l}\text { Tourism- } \\
\text { Commercial-Culture }\end{array}$ & 0 & $0 \%$ & 17.21 & $3.59 \%$ \\
\hline Tourism-Commercial & 0 & $0 \%$ & 19.28 & $4.02 \%$ \\
\hline Logistic Facility Area & 0 & $0 \%$ & 3.96 & $0.82 \%$ \\
\hline Roads & 72.80 & $15.17 \%$ & 92.78 & $19.33 \%$ \\
\hline Free Space & 52.22 & $10.88 \%$ & 0.00 & 0 \\
\hline Inactive Buildings & 28.72 & $5.98 \%$ & 0.00 & 0 \\
\hline Construction Sites & 16.50 & $3.44 \%$ & 0.00 & $0 \%$ \\
\hline Special Project Area & 0 & $0 \%$ & 7.00 & $1.46 \%$ \\
\hline
\end{tabular}

The change in land use pattern, which is one of the radical changes foreseen by NCC plans, causes a great change in space user profile with the organization of the space. From this point of view, the process of converting storage and industrial areas into CBD and tourism use means the change of the user group as well as the physical change in the area that accounts for about $70 \%$ of NCC. However, the storage and industrial areas covering a large part of 
the area being replaced by the use of the central business area and tourism-commerce area, tourism-trade-culture area points out that the production potential of the area is completely eliminated. Thus, it is possible to say that the spatial transformation in NCC affects the whole area and also that it proceeds in a multidimensional way enough to change the balance of the productionconsumption activities and change the user profile correspondingly.

\section{Change in Property pattern in NCC}

The change of land use pattern in NCC has revived the change of property pattern. The property pattern is very important because it is closely related to the user profile of the area as well as the distribution of rent to be obtained. Although a large part of the projects in NCC have previously chosen a place on the plots belonging to private property, approximately half of these plots are composed of plots belonging to private ownership. During the handover of the property, the floors are usually increased and the high-rise buildings are provided by this way. When the ownership data for the project areas are analyzed quantitatively, it is not possible to fully see the extent of the change of the ownership of public ownership. However, it should not be overlooked that the Izmir Port Project, which is one of the selected projects, has a large area of 163 hectares directly affects the quantitative data. In light of this information, it is clear that public areas in the area have been privatized and that private sector ownership in the area has tripled by means of both procurement and privatization.

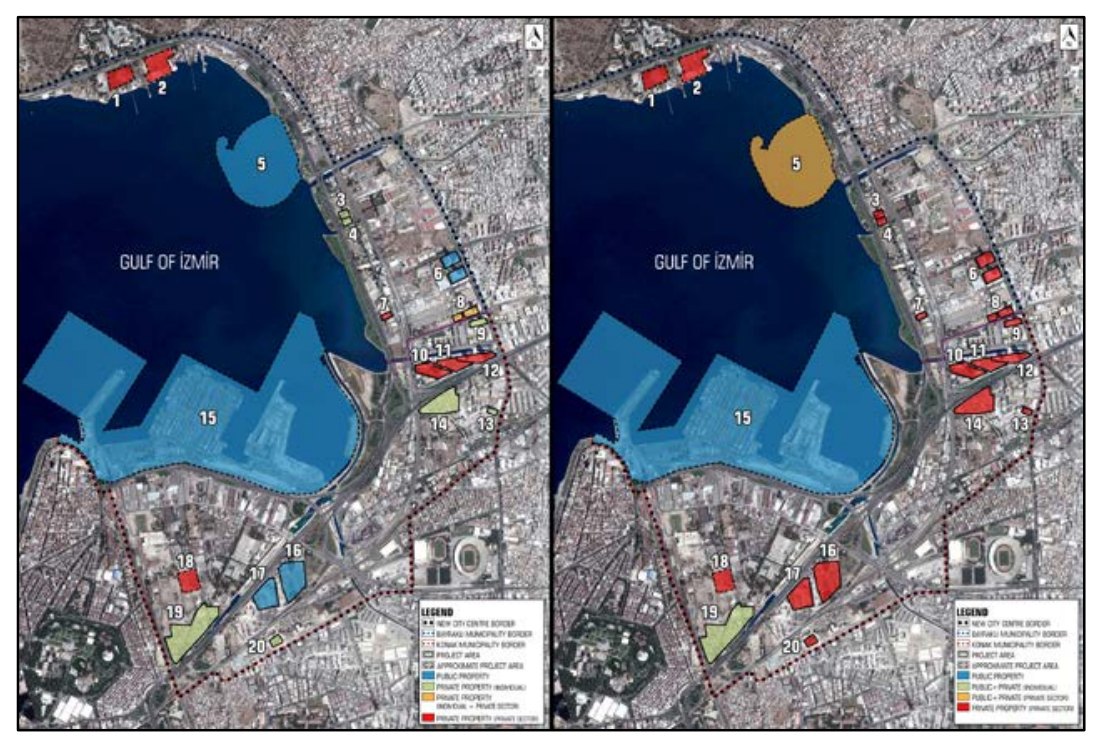

Figure 10. Property status before and after selected projects (Drawing by author) 
Table 5. Value of property status before and after selected projects

\begin{tabular}{|l|r|r|r|r|}
\hline \multicolumn{1}{|c|}{ Property Status } & \multicolumn{1}{c|}{$\begin{array}{c}\text { Before } \\
\text { Projects } \\
\text { (hectare) }\end{array}$} & \multicolumn{1}{c|}{$\begin{array}{c}\text { Percentag } \\
\text { e }\end{array}$} & \multicolumn{1}{c|}{$\begin{array}{c}\text { After } \\
\text { Projects } \\
\text { (hectare) }\end{array}$} & Percentage \\
\hline Public Property & 197.56 & $89.42 \%$ & 163.69 & $74.09 \%$ \\
\hline Private Property (Individual) & 11.43 & $5.18 \%$ & 0 & $0 \%$ \\
\hline $\begin{array}{l}\text { Private Property } \\
\text { (Public Sector) }\end{array}$ & 11.11 & $5.03 \%$ & 25.23 & $11.42 \%$ \\
\hline $\begin{array}{l}\text { Private Property } \\
\text { Individual+Private Sector) }\end{array}$ & 0.82 & $0.37 \%$ & 0 & $0 \%$ \\
\hline $\begin{array}{l}\text { Public Property+ Private } \\
\text { Property (Individual) }\end{array}$ & 0 & $0 \%$ & 6.38 & $2.89 \%$ \\
\hline $\begin{array}{l}\text { Public Property+Private } \\
\text { Property (Private Sector) }\end{array}$ & 0 & $0 \%$ & 25.63 & $11.60 \%$ \\
\hline
\end{tabular}

Although the public-private balance in the property pattern has been generally preserved, in the areas belonging to private ownership, property has emerged from large-scale investors or individuals and the ownership changed to large-scale capital groups. In addition, it is observed that the previously publicly owned areas (certain parts of the coastal strip with public plots) are privatized directly through projects carried out by the private sector or through joint projects with the private sector. It is possible to say that the change in the property pattern created by the privatization process realized is multidimensional when it is taken into consideration that the projects of Folkart Towers and Mahall Bomonti Izmir in subject areas that have transferred from public property to private property and Bayraklı Marina Project in the coastal area that have transferred from public property to public and private property have chosen place.

\section{Change in Urban Rent in NCC}

The transformation in NCC brings along the increase of urban rent. In order to clarify the increase in rent transparently, $\mathrm{m} 2$ unit rent prices of residential and commercial areas of İzmir, Bayrakl, Konak and Adalet districts that whole of it is within the NCC boundaries and Alsancak, Kültür, Mansuroğlu and Tuna districts located around the NCC have been taken into consideration. When the changes in the real estate index are considered, it is seen that the settlements in the housing and trade areas have quite different values in the last four periods. When examined on the basis of district, it is seen that the trade index (\%75.69) of the Adalet District, where mostly projects with office functions are produced, is approximately 1.5 times that of the provincial (47.30\%) and county (59.66\%) values. Besides, Mansuroglu District, that is adjacent to Ege Perla and Mistral İzmir, which are the highest prestigious projects in NCC is coming into prominence among the other neighborhoods in terms of residence $(77.29 \%)$ and trade indexes $(113.17 \%)$. 
Table 5. Value of property status before and after selected projects (Sahibinden, 2018)

\begin{tabular}{|l|r|r|r|r|}
\hline \multirow{2}{*}{ Location } & \multicolumn{2}{|c|}{ Housing } & \multicolumn{2}{c|}{ Commercial } \\
\cline { 2 - 5 } & 1 Year & \multicolumn{1}{c|}{ 4 Year } & \multicolumn{1}{c|}{ 1 Year } & \multicolumn{1}{c|}{ 4 Year } \\
\hline İzmir & 4.86 & 70.72 & 10.05 & 47.30 \\
\hline Bayraklı & 4.49 & 56.95 & 7.00 & 59.66 \\
\hline Konak & 6.51 & 74.97 & 10.62 & 47.77 \\
\hline Adalet District & 9.86 & 28.23 & 6.17 & 75.69 \\
\hline Alsancak District & 6.77 & 37.37 & 10.17 & 47.85 \\
\hline Kültür District & -1.44 & 43.88 & 8.62 & 34.10 \\
\hline Mansuroğlu District & 9.07 & 77.29 & 9.50 & 113.17 \\
\hline Tuna District & 15.97 & 54.81 & 11.29 & 74.68 \\
\hline
\end{tabular}

It is seen that the increase in the amount of rent has reached the highest level in NCC and its immediate vicinity. However, it is foreseen that the existing industrial and storage areas within the NCC will be transformed as CBD and tourism areas with plans; because the industrial and storage areas need large floor space by their structure, they have direct effects on urban rent increase in the process of land use pattern transformation. It is possible to say that these plots have a target market consisting of only large-scale investors as they have very high sales prices ranging between $71,560,000$ TRY and 538,050,000 TRY. However, when the price range is evaluated, it is seen that the sales prices of the residence $(855,001$ TRY - 1,600,000 TRY) and commercial $(2,672,316$ TRY $8,000,000$ TRY) units in the immediate vicinity of NCC are lower than residence $(1,600,001$ TRY - 2,152,200 TRY) and commercial $(8,000,001 \mathrm{TRY}-15,000,000 \mathrm{TRY})$ units in large scale projects.

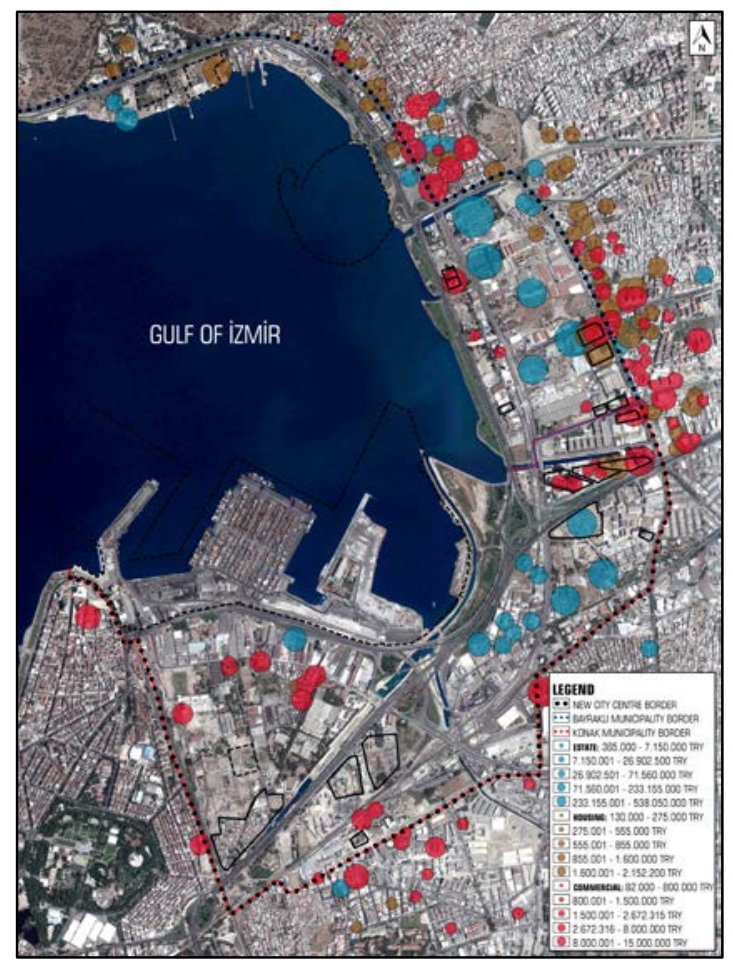

Figure 11. NCC and surroundings land for sale, housing and trade unit prices (Edited from data of Sahibinden, 2017) 
https://www.emlaksayfasi.com.tr/i zmir-emlak-haberleri/izmirbayrakli-da-yeni-kent-merkeziprojesi-bolgedeki-fiyatlari-arttirdih34187.html, Accessed18 May 2018; http://www.thepicta.com/m edia/1365149897523166231_1612 534262, Accessed 18 May 2018; http://www.egehaber.com/izmir/y eni-kent-merkezi-ucacak-h63660.ht ml, Accessed 18 May 2018

Figure 12. NCC view before 2011, The present state of the NCC silhouette and the silhouette planned to be owned by 2030
There is a significant relationship between the increase in rent in NCC and large-scale urban projects. When the changes in the real estate indexes of the selected settlements are examined, it is possible to tell that there is direct proportion between changes in the real estate indexes and the closeness of the settlements to NCC and thus the prestigious projects within. In addition, it is observed that urban rent is rapidly transformed within NCC and around it, especially in Salhane Region, where the land, residence and trade units are mainly concentrated in sales. Hence, it is possible to say that the encountered process will make NCC a significant capital accumulation point in the city both locally and nationally.

\section{Change in the City Silhouette}

The change of the city silhouette in Salhane Region, which is the area where the effects of the projects are clearly read, started with the first high-rise building, My Plaza, which started construction in 2000 and accelerated with the completion of the master plans for the area in 2011. Although the silhouette of the Salhane Region started to develop in the vertical direction, because of the fact that the buildings are scattered throughout the area, it is seen that it disrupts the continuity on the city silhouette. While the continuity of the silhouette is expected to be provided in 2030, which is the target year of the plans, it is seen that the structures remaining on the coastline will play a predominant role on the silhouette of the city. ${ }^{1}$

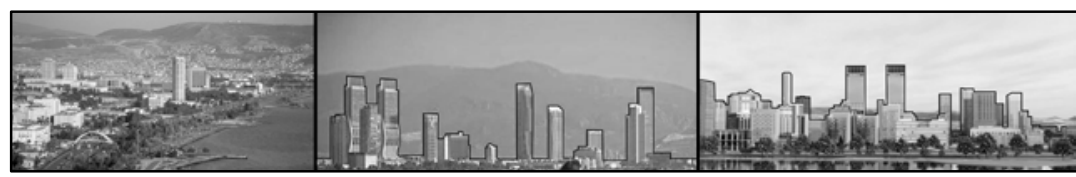

The transformation in the Salhane Region, where the impact of the projects on the city silhouette is clearly read, is relatively slow in Turan and Alsancak Port-Back Area and provides foresight about the change. When the future projects that are expected to select place in NCC are examined, it is possible to say that the planned investments will gradually increase the urban silhouette in the vertical plane. This blazing transformation in the city silhouette can be evaluated as the spatial manifesto of neoliberal urbanization in İzmir.

\section{CONCLUSION}

Along with the direction of the capital to big metropolitan cities, especially Istanbul in the context of neoliberal urbanization trends in Tukey, İzmir NCC stands out as one of the most important areas of application of neoliberal urbanization. When the process in İzmir NCC is examined closely; it is seen that the 
plan decisions that are shaped around the vision of making the city attractive for capital, especially in the context of land use decisions and the production-consumption activities in the area, form a basis for the start of a major transformation process in the Turan, Salhane and Port Back Regions that are within the boundaries of NCC. Large-scale urban projects, which are implemented on the basis of plan decisions, are the main carriers of the neoliberal spatial transformation process in NCC due to both project contents and their spatial effects. These projects have become larger scale, more complex in terms of their functions and have high investment costs and have become the focus of neoliberal urbanization.

It is possible to classify the effects of the transformation process executed under the leadership of large-scale urban projects of the private sector on the NCC and therefore the city:

- The city of İzmir, with its $1 / 5000$ İzmir New City Centre Master Plan, which was approved in 2003, has acquired a new centre under the name of NCC which is the product of a partial planning approach in addition to the traditional city centre which has a long history in the city. This decision signifies a very radical change for all city and citizens. This situation has left an area, that lacks the necessary conditions to become a city centre, under pressure. In the region, at the very time, the main decisions that are placed in the focus of neoliberal urban policies and the office, luxury housing, shopping mall, marina, hotel etc. brought by these decisions have created a city centre that will enable the neoliberal productionconsumption relations in which the underlying functions are integrated into a splendid architecture vertically.

- As a requirement of the functions attributed to NCC, the land use pattern completely differentiates from the current situation and changes in favor of consumption areas, which in turn brings with it a new user group that can meet the costs of this new spatial structuring.

- Due to the conditions of structuring that facilitate high density, the city undergoes a transformation in this region in a vertical direction which differs considerably from other parts of the city, which changes the urban silhouette rapidly and radically.

- Through the privatization, which is one of the most basic tools used by neoliberal urbanization to transform the space, some public property areas in NCC are seen to be privatized. Thus, whether through privatization or purchase, many plots in the area go directly into the 
control of large-scale capital, which leads to the change of property pattern in favor of large-scale capital.

- On the basis of all these developments, there is an increase in urban rent in the area and the change in urban rent operates in favor of large-scale capital groups operating in the speculative real estate sector.

- Subject transformations cause urban residents, who cannot tolerate the increase in urban rent and cannot be resistant against this process, not to make their presence felt and also cause urban disintegration.

In this context, the urban space in NCC is undergoing a radical transformation in the neoliberal urbanization axis. The reproduction process of the space in NCC creates areas that will meet the needs of neoliberal urbanization. On the basis of the above parameters, the new functions that the New City Centre brought on the space and the language of planning it has established related to the placement of these functions, along with the new architectural view it has put on, it has become more specialized for citizens living in that region, its immediate vicinity and whole city in terms of physical, economical and sociological, lead to a neoliberal spatial pattern, which the use value has transformed in favor of higher income groups. This makes the principle of the use of all urban space on the basis of the principle of public interest, which is one of the fundamental principles of urban planning for all classes in the city, to be questioned. In this context, it is important that all national and local initiatives, especially residents and local governments that produce plan decisions to show awareness and develop positive solution offers in this respect. At this point, the study draws attention to the drawbacks of the process of neoliberal urbanization in NCC while revealing transformation of the space process of neoliberal urbanization with its outputs. In this respect, the study emphasizes that the process of the NCC in a broad perspective, which has recently found a place itself in the literature, and that urban actors should approach the future of the city in terms of public interest, not capital. In addition to its importance at the local level, the study is located at an important point on the global scale in terms of revealing the effects of neoliberal urbanization processes under the leadership of large-scale urban projects in developing countries.

\section{ACKNOWLEDGMENT}

This article is produced under the MSc Thesis titled 'Reproduction of Space in the Context of Neoliberal Urbanism: The Case Study of İzmir New City Centre' by Özgün Tutar in consultation with Eylem 
Bal, within Dokuz Eylul University The Graduate School of Natural and Applied Sciences City And Regional Planning MSc Programme.

\section{REFERENCES}

Andersen, B., \& Røe, P. G. (2017). The social context and politics of large scale urban architecture: Investigating the design of Barcode, Oslo. European Urban and Regional Studies, 24 (3), 304-317.

Bal, E. (2011). Türkiye'de 2000 sonrası neoliberal politikalar çerçevesinde imar mevzuatındaki değişimler ve yeni kentleşme pratikleri: İstanbul örneği [Changes about development law and new urbanization practices in the frame of neoliberal politics in Turkey after 2000's: The case study of Istanbul] (Doctoral dissertation). Dokuz Eylül University, İzmir.

Bal, E. \& Akyol Altun, D. (2016). İzmir'de neoliberal kentleşme eğilimleri kapsamında lüks konut üretiminde yeni yaklaşımlar: Folkart konut projeleri [New approaches to luxury housing construction in İzmir in the context of neoliberal urbanization: Folkart housing projects]. Planlama Dergisi, 26 (1), 65-80.

Bénit-Graffou, C., Didier, S. \& Peyroux, E. (2012). Circulation of security models in Southern African cities: Between neoliberal encroachment and local power dynamics. International Journal of Urban and Regional Research, 36 (5), 877-889.

Borsuk, I. \& Eroğlu, E. (2019). Displacement and asset transformation from inner-city squatter settlement into peripheral mass housing. European Urban and Regional Studies, 1-14.

Brenner, N. \& Theodore, N. (2002). Cities and the geographies of "actually existing neoliberalism". Antipode: A Radical Journal of Geography, 34 (3), 349-379.

Burgers, J. \& Van Der Waal, J. (2008). Globalizing urban economies and social inequality: An empirical assessment. The case of Amsterdam and Rotterdam. In P. Ache, H. T. Andersen, T. Maloutas, M. Raco, \& T. Taşan-Kok (Ed.) Cities between competitiveness and cohesion discourses, realities and implementation (79-98) New York: Springer Science+Business Media.

Ellis, R. (2012). “A world class city of your own!": Civic governmentality in Chennai. India. Antipode: A Radical Journal of Geography, 44 (4), 1143-1160.

Enright, T. E. (2014). Illuminating the Path to Grand Pari(s): Architecture and urban transformation in an era of 
neoliberalization. Antipode: A Radical Journal of Geography, 46 (2), 382-403.

Eraydın, A. (2011). Changing istanbul city region dynamics: Reregulations to challenge the consequences of uneven development and inequality. European Planning Studies, 19 (5), 813-837.

Evans, G. (2005). Measure for measure: evaluating the evidence of culture's contribution to regeneration. Urban Studies, 42 (5), 1-25.

Gomez, P. (2019). The birth of public space privatization: How entrepreneurialism, convivial urbanism and stakeholder interactions made the Martim Moniz square, in Lisbon, "privatization-ready". European Urban and Regional Studies, 1-15.

Güzey, Ö. (2014). Neoliberal urbanism restructuring the city of Ankara: Gated communities as a new life style in a suburban settlement. Cities, 36, 93-106.

Güzey, Ö. (2016). The last round in restructuring the city: Urban regeneration becomes a state policy of disaster prevention in Turkey. Cities, 50, 40-53.

Hackworth, J. R. (2007). The neoliberal city. New York: Cornell University Press.

Harvey, D. (2015). Neoliberalizmin kısa tarihi [Brief history of neoliberalism] (A. Onacak, Trans.). İstanbul: Sel Yayıncılık (Original 2005).

He, S. \& Wu, F. (2009). China's emerging neoliberal urbanism: Perspectives from urban redevelopment. Antipode: A Radical Journal of Geography, 41 (2), 282-304.

Kozanoğlu, H., Gür, N., \& Özden, B. A. (2015). Neoliberalizmin gerçek 100'ü [Real 100 of neoliberalism] (3rd ed.). İstanbul: İletişim Yayınları.

Kunzmann, K. R. (2016). Crisis and urban planning? A commentary. European Planning Studies, 24 (7), 13131318.

Lemansk, C. (2007). Global Cities in the South: Deepening social and spatial polarization in Cape Town. Cities, 24 (6), 448461.

Lin, G. C. S., \& Zhang, A. Y. (2015). Emerging spaces of neoliberal urbanism in China: land commodification, municipal finance and local economic growth in prefecture-level cities. Urban Studies, 52 (15), 2774-2798.

MacDonald, I. T. (2011). Bargaining for rights in luxury city: The strategic dilemmas of organized labor's urban turn. Labor Studies Journal, 36 (2), 197-220.

Marquardt, N. \& Füller, H. (2012). Spillover of the private city: BIDs as a pivot of social control in downtown Los Angeles. European Urban and Regional Studies, 19 (2), 153-166. 
Mayer, M. (2017). Whose city? from Ray Pahl's critique of the Keynesian city to the contestations around neoliberal urbanism. The Sociological Review, 65 (2), 168-183.

Odeh, L. E. (2010). A comparatıve analysis of global North and global South economies. Journal of Sustainable Development in Africa, 12 (3), 338-348.

Radice, H. (2007). Neoliberal küreselleşme: İmparatorlukların olmadığı bir emperyalizm mi? [Neoliberal globalisation: Imperialism without empires?]. In A. Saad Filho \& D. Johnston (Ed.). Neoliberalizm muhalif bir seçki [Neoliberalism: A critical reader] (155-168). (Ş. Başlı \& T. Öncel, Trans). İstanbul: Yordam Kitap (Original 2005).

Rankin, K., \& Delaney, J. (2010). Community bias as practices of assemblage: Contingent politics in the neoliberal city. Environment and Planning A: Economy and Space, 43 (6), 1363-1380.

Robins, K. \& Aksoy, A. (1995). İstanbul rising: Returning the repressed to urban culture. European Urban and Regional Studies, 2 (3), 223-235.

Sassen, S. (1991). The global city: New York, London, Tokio. New Jersey: Princeton University Press.

Smith, N. (2002). New globalism, new urbanism: Gentrification as global urban strategy. Antipode: A Radical Journal of Geography, 34 (3), 427-450.

Swyngedouw, E., Moulaert, F., \& Rodriguez, A. (2002). Neoliberal urbanization in Europe: Large-scale urban development projects and the new urban policy. Antipode: A Radical Journal of Geography, 34 (3), 542-577.

Şanl, T., \& Townshend, T. (2018). Hegemonic power relations in real practices of spatial planning: The case of Turkey. European Planning Studies, 26 (6), 1242-1268.

Taşan-Kok, T. (2012). Introduction: Contradictions of neoliberal urban planning. In T. Taşan-Kok \& G. Baeten (Ed.). Contradictions of neoliberal urban planning: Cities, policies, and politics (1-20). New York: Springer Science+Business Media.

Taşan-Kok, T. (2015). Analysing path dependence to understand divergence: Investigating hybrid neo-liberal urban transformation processes in Turkey. European Planning Studies, 23 (11), 2184-2209.

Theodore, N. \& Peck, J. (2011). Framing neoliberal urbanism: Translating 'commonsense' urban policy across the OECD zone. European Urban and Regional Studies, 19 (1), 20-41.

Yıldız, Ö. (2014). Osmanlı Devleti'nde deniz ticareti (1908-1914) [Maritime trade in the Ottoman state]. İstanbul: Tarihçi Kitabevi Yayınları. 


\section{Plans:}

Başbakanlık Özelleştirme İdaresi Başkanlığı. (2008). İzmir İli Karşıyaka İlçesi Salhane Mahallesi 1134 Ada, 4 Parsel 1/5000 Ölçekli Nazım İmar Planı

Başbakanlık Özelleştirme İdaresi Başkanlığı. (2012a). İzmir İli Konak İlçesi Halkapınar 1443 Ada 37 ve 1454 Ada 23 Parseller 1/5000 Ölçekli Nazım İmar Planı Değişikliği

Başbakanlık Özelleştirme İdaresi Başkanlığı. (2012b). İzmir Kruvaziyer Liman Alanı Nazım İmar Planı Değişikliği (1/25000 Ölçek)

Başbakanlık Özelleştirme İdaresi Başkanlığı. (2012c). İzmir Kruvaziyer Liman Alanı Nazım İmar Planı Değişikliği

Başbakanlık Özelleştirme İdaresi Başkanlığı. (2014). İzmir İli Konak İlçesi Mersinli Mahallesi 2876 Ada 12 Parsel Nazım İmar Planı Değişikliği

Başbakanlık Özelleștirme İdaresi Başkanlığı. (2015a). İzmir Yük Limanı İzmir Büyükșehir Bütünü Çevre Düzeni Planı Değişikliği (1/25000 Ölçek)

Başbakanlık Özelleştirme İdaresi Başkanlığı. (2015b). İzmir Kruvaziyer Liman Alanı Nazım İmar Planı Değișikliği

Başbakanlık Özelleştirme İdaresi Başkanlığı. (2015c). İzmir Yük Limanı Nazım İmar Planı Değişikliği

Başbakanlık Özelleştirme İdaresi Başkanlığı. (2016a). İzmir Yük Limanı İzmir Büyükșehir Bütünü Çevre Düzeni Planı Değişikliği (1/25000 Ölçek)

Başbakanlık Özelleştirme İdaresi Başkanlığı. (2016b). İzmir Kruvaziyer Liman Alanı Nazım İmar Planı Değişikliği

Başbakanlık Özelleştirme İdaresi Başkanlığı. (2016c). İzmir Yük Limanı İlave ve Revizyon Nazım İmar Planı

Bayraklı Belediyesi. (2016). Bayraklı Yeni Kent Merkezi Uygulama İmar Planı

Çevre ve Șehircilik Bakanlı̆̆ı. (2017). İzmir İli, Konak İlçesi, Kuruçay ve Umurbey Mahalleleri, 7839 Ada 1 Parsel, 7840 Ada 1 Parsel, 1384 Ada Muhtelif Parseller, 1445 Ada Muhtelif Parseller, 1448 Ada Muhtelif Parseller ve Yakın Çevresine İlișkin 1/5000 Ölçekli Nazım İmar Planı Değişikliği

İzmir Büyükşehir Belediyesi. (1989). İzmir Büyüksehir Bütünü Nazım Plan Revizyonu

İzmir Büyükşehir Belediyesi. (2001). İzmir Liman Bölgesi İçin Kentsel Tasarım Uluslararası Fikir Yarıșma Șartnamesi

İzmir Büyükşehir Belediyesi. (2003). 1/5000 İzmir Yeni Kent Merkezi Nazım İmar Planı

İzmir Büyükșehir Belediyesi. (2007). 1/25000 Ölçekli İzmir Kentsel Bölge Nazım İmar Planı

İzmir Büyükşehir Belediyesi. (2008). 1/25000 Ölçekli İzmir Kentsel Bölge Nazım İmar Planı 
İzmir Büyükşehir Belediyesi. (2009). 1/25000 Ölçekli İzmir Kentsel Bölge Nazım İmar Planı

İzmir Büyükşehir Belediyesi. (2010). 1/5000 Ölçekli İzmir Yeni Kent Merkezi Nazım İmar Planı

İzmir Büyükşehir Belediyesi. (2011). 1/5000 Ölçekli İzmir Yeni Kent Merkezi Nazım İmar Planı

İzmir Büyükşehir Belediyesi. (2012). 1/25000 Ölçekli İzmir Büyükşehir Bütünü Çevre Düzeni Planı

İzmir Metropoliten Alan Nazım İmar Planı Bürosu. (1973). İzmir Metropoliten Alan Nazım İmar Planı

Konak Belediyesi. (2016a). Alsancak Liman Arkası ve Salhane Bölgesi 1/1000 Ölçekli İmar Planı Plan Notları (Halkapınar-Salhane Kesimi)

Konak Belediyesi. (2016b). İzmir İli, Konak İlçesi, Umurbey Mahallesi, 1392 Ada 12, 13, 14, 15, 16, 17, 18, 21, 22

Parsellere İlişkin 1/1000 Ölçekli Uygulama İmar Planı Değişikliği

Konak Belediyesi. (2016c). İzmir İli Konak İlçesi 1445 Ada Uygulama İmar Planı Değişikliği

Online Resources 1 (Accessed 27 December 2018)

http://www.atertower.com/\#

http://www.egeperla.com.tr

http://folkarttowers.com/

https://folkartvega.com/

http://mcarsikule.com/\#!

http://www.megapolgroup.com/

http://www.mistralizmir.com.tr/

http://www.myplaza.com.tr/

http://www.myway.com.tr/projelerimiz.html

http://www.novusventus.com/

http://mahallbomontiizmir.com/

http://rgy.com.tr/tr/projects/izmir-turan-project

http://www.ronesanskonut.com.tr/projeler/devam-eden-projel er/izmir-turan-karma-kullanim-projesi

https://www.suryapi.com.tr/avm-projeleri/sur-yapi-izmir-marb ina-park

http://www.yapitsan.com.tr/ProjeDetay.aspx?Id=161

http://www.yenibirinsaat.com/index.php/taris-tower

http://https://www.yeniprojeler.comww.guncelprojebilgileri.co

$\mathrm{m}$

Online Resources 2 (Accessed 27 December 2018)

http://www.ardaliinsaat.com/cloud/331.jpg

http://folkartvega.com/galeri.php\#gallery-10

http://www.egemak.biz/dosya/82daf72f6c..jpg

http://www.egeperla.com.tr/img2/AVM/9.jp

https://www.emlakbulten.com/wp-content/uploads/Izmir-Mari na-Park.jpg 
http://i.emlaktasondakika.com/Files/EditorImages/images/yen ibir.jpg

http://dekoral.org/v5/wp-content/uploads/2014/01/Folkart9.jpg

http://i62.tinypic.com/b9buxi.jpg

http://mahallbomontiizmir.com/images/innerPages/archConce pt/olm akistediginyer_big.jpg

https://www.mcarsikule.com/Megapol/GaleriDetay/1/dis_mek an.html

http://www.megapolgroup.com/assets/upload/02-1_2127-120 .jpg

http://www.mistralizmir.com.tr/img/MISTRAL_KATALOG_2702 2017.pdf

http://www.myway.com.tr/myway-rodkar-kule.html

http://projefirsatlari.com/wp-content/uploads/2016/06/AtekAdress.jpg

http://www.tekfengayrimenkul.com/izmir-projesi.aspx

http://www.yapitsan.com.tr/img/78c05e79-cff6-4ab9-893a-42 6aad1fe 685.jpg

http://3dkonut.com/Resimler/Projeler/novus---ventus/Vaziyet Plan/no vus---ventus_3660.png

https://3dkonut.com/resimler/projeler/ronesans-turan/3dresi mler/ronesans-turan_9227.png

\section{Resume}

Özgün Tutar received MSc degree in City and Regional Planning from Dokuz Eylül University, İzmir. Özgün Tutar's reserch interests are neoliberal urbanization, public welfare, city branding and planning politics.

Eylem Bal received BSc, MSc and PhD degrees in City and Regional Planning from Dokuz Eylul University, Izmir. Currently, she is working as an Assistant Professor in the City and Regional Planning department at the same University. Her research interests are neoliberal urbanization, planning law, public interest and urban transformation. 